\title{
Ni-Catalyzed Synthesis of Fluoroarenes via [2+2+2] Cycloaddition Involving $\alpha$-Fluorine Elimination
}

\author{
Takeshi Fujita, Yota Watabe, Tomohiro Ichitsuka, and Junji Ichikawa*
}

\begin{abstract}
A method for direct synthesis of tetrasubstituted fluoroarenes via nickel-catalyzed [2+2+2] cycloaddition is presented. The reaction combines one molecule of 1,1-difluoroethylene with two molecules of alkynes and involves sequential cleavage of the $\mathrm{C}-\mathrm{F}$ and $\mathrm{C}-\mathrm{H}$ bonds in difluoroethylene. The catalytic cycle is established by reduction of the intermediary $\mathrm{Ni}(\mathrm{II})$ fluoride with a triethylboranebased borate.
\end{abstract}

Application of fluoroarenes in the fields of pharmaceutical and materials sciences has resulted in considerable efforts toward development of methods for their synthesis. ${ }^{[1]}$ Traditionally, fluoroarenes are synthesized via decomposition of aryl diazonium tetrafluoroborates (the Balz-Schiemann reaction) ${ }^{[1 \mathrm{~b}, 2]}$ or nucleophilic substitution of electron-deficient aryl halides with fluoride salts (the Halex reaction). ${ }^{[1 \mathrm{~b}, 3]}$ Recent developments in fluorinating reagents have given rise to other alternatives for the synthesis of fluoroarenes, including (i) reactions of aryl nucleophiles with electrophilic fluorine $\operatorname{sources}^{[1 b, 4]}$ and (ii) reactions of aryl electrophiles with nucleophilic fluorine sources. ${ }^{[5]}$ Furthermore, the use of transition metal catalysts has enabled directing group-assisted aromatic $\mathrm{C}-\mathrm{H}$ bond fluorination, ${ }^{[1 \mathrm{~b}, \mathrm{c}, \mathrm{e}, 6]}$ fluorination of arylmetals, ${ }^{[1 \mathrm{c}, 7]}$ and fluorination of nonactivated aryl halides (Scheme 1a). ${ }^{[\mathrm{b}-\mathrm{e}, 8]}$ Thus, conventional methods for synthesizing fluoroarenes require regioselective prefunctionalization on benzene rings.

Recently, we reported the nickel-mediated [3+2] cycloaddition of 2-trifluoromethyl-1-alkenes and alkynes. ${ }^{[9]}$ During this cycloaddition, two $\mathrm{C}-\mathrm{F}$ bonds are cleaved via $\beta$ fluorine elimination, a characteristic feature of fluorine-containing organometallic compounds and two $\mathrm{C}-\mathrm{C}$ bonds are constructed instead. ${ }^{[9,10]}$ Despite the loss of two fluorine substituents from the trifluromethyl group, the surviving fluorine substituent is regioselectively installed in the final cyclopentadiene products. On the other hand, when 1,1-difluoroethylene was reacted as a fluorinated component with alkynes in the presence of $\mathrm{Ni}(0)$ complex, fluoroarenes were directly obtained. Here, we demonstrate that the combination of 1,1-difluoroethylene and alkynes via nickel-catalyzed $[2+2+2]$ cycloaddition is an alternative method for the synthesis of fluoroarenes (Scheme 1b). ${ }^{[11,12]}$ Although transition-metal-catalyzed [2+2+2] cycloaddition is a facile method for the construction of benzene ring from three alkyne molecules, ${ }^{[11]}$ similar syntheses involving

${ }^{\star}{ }^{\star} \quad$ Dr. T. Fujita, Y. Watabe, Dr. T. Ichitsuka, Prof. Dr. J. Ichikawa Division of Chemistry

Faculty of Pure and Applied Sciences

University of Tsukuba, Tsukuba, Ibaraki 305-8571 (Japan)

Fax: (+81) 29-853-4237

E-mail: junji@chem.tsukuba.ac.jp

Supporting information for this article is given via a link at the end of the document. alkene substrates require an additional oxidation ${ }^{[12 a, c]}$ or elimination ${ }^{[13]}$ step to ensure aromatization. By contrast, our protocol allows for direct construction of benzene ring through nickel-promoted $\alpha$-fluorine elimination ${ }^{[14,15]}$ as the key elementary step.

(a) Conventional methods

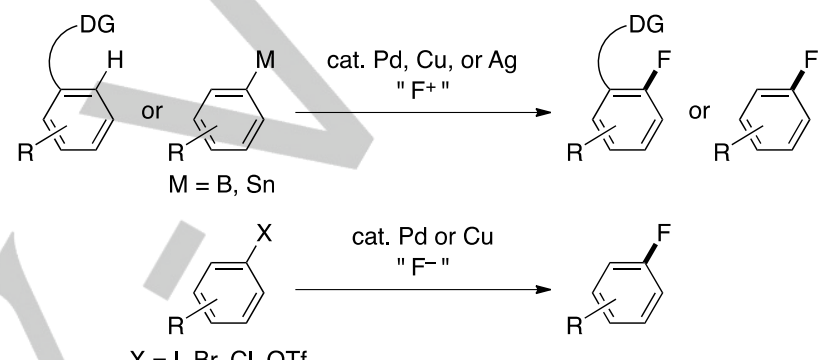

(b) This work

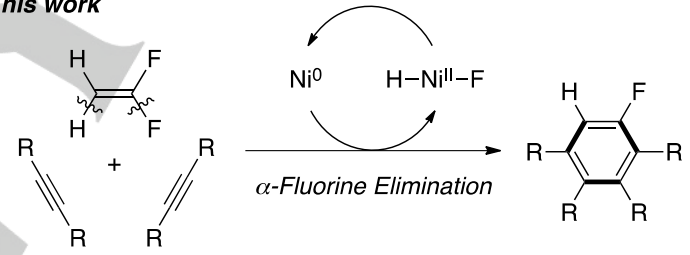

Scheme 1. Transition-metal-catalyzed syntheses of fluoroarenes.

First, we sought suitable conditions for the [2+2+2] cycloaddition reaction of 1,1-difluoroethylene $(1,2.3 \mathrm{mmol})$ and diphenylacetylene $(2 \mathrm{a}, 0.50 \mathrm{mmol})$ in the presence of a catalytic amount of a Ni(0) complex (Table 1). The choice of ligands used with $\mathrm{Ni}(\operatorname{cod})_{2}(5 \mathrm{~mol} \%$ based on the amount of $\mathbf{2 a}$ ) was critical for the efficiency of the reaction. Use of IMes. $\mathrm{HCl}$ with $\mathrm{KH}(5$ mol\% each) or $\mathrm{P}(\mathrm{tBu})_{3}(10 \mathrm{~mol} \%)$ afforded 1-fluoro-2,3,4,5tetraphenylbenzene (3a), albeit in low yields (Entries 2 and 4). Among the ligands examined, $\mathrm{PCy}_{3}(5 \mathrm{~mol} \%)$ was found to be the best (Entry 6). No improvement in reaction yields was observed using bases, such as Hünig's base and DBU, which suggested that fluoroarene $\mathbf{3 a}$ might be formed directly and not via a HF elimination after the formation of $4 a$ (Entries 9 and 10). Addition of $\mathrm{Et}_{3} \mathrm{SiH}, \mathrm{PrOLi}$, or iPrOBpin (Entries 11-13) was only marginally effective in increasing the yield of the reaction. However, $\mathrm{Et}_{3} \mathrm{~B}$ indicated potential for regeneration of the nickel catalyst (Entry 14). To activate $\mathrm{Et}_{3} \mathrm{~B}$, iPrOLi was added to improve the turnover number of the $\mathrm{Ni}(0)$ complex significantly (Entry 15). Finally, the use of equimolar quantities of 1 and $2 a$ afforded $3 \mathbf{a}$ in $82 \%$ isolated yield (Entry 16 ).

Table 1. Optimization of Reaction Conditions for the Ni-Catalyzed $[2+2+2]$ Cycloaddition $^{[\mathrm{a}]}$ 


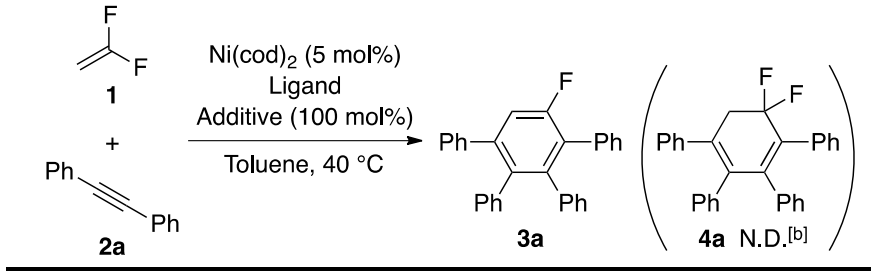

\begin{tabular}{|c|c|c|c|c|}
\hline Entry & Ligand (mol\%) & Additive & Time [h] & $\mathbf{3 a}[\%]^{[\mathrm{c}]}$ \\
\hline 1 & - & - & 14 & N.D..$^{[b]}$ \\
\hline 2 & IMes· $\mathrm{HCl}(5)^{[\mathrm{d}]}$ & - & 14 & 4 \\
\hline 3 & dppp (5) & - & 22 & N.D..$^{[b]}$ \\
\hline 4 & $\mathrm{P}(t \mathrm{Bu})_{3}(10)$ & - & 14 & 3 \\
\hline 5 & РСу $y_{3}(10)$ & - & 22 & 9 \\
\hline 6 & РСуз (5) & - & 22 & 8 \\
\hline 7 & $\mathrm{PCy}_{3}(5)$ & LIOAC & 22 & 9 \\
\hline 8 & РСуз (5) & $\mathrm{Et}_{3} \mathrm{~N}$ & 22 & 7 \\
\hline 9 & 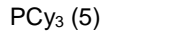 & $\mathrm{PPr}_{2} \mathrm{NEt}$ & 7 & 10 \\
\hline 10 & РСуз (5) & DBU & 7 & 9 \\
\hline 11 & РСу⿰丬士 (5) & $\mathrm{Et}_{3} \mathrm{SiH}$ & 9 & 20 \\
\hline 12 & РСуз (5) & iPrOLi & 15 & 37 \\
\hline 13 & РСу & iPrOBpin & 31 & 26 \\
\hline 14 & РСуз (5) & $\mathrm{Et}_{3} \mathrm{~B}$ & 22 & 44 \\
\hline 15 & РСуз (5) & $\mathrm{Et}_{3} \mathrm{~B}+i \mathrm{PrOLi}$ & 12 & $83(80)$ \\
\hline $16^{[\mathrm{e}]}$ & РСуз (5) & $\mathrm{Et}_{3} \mathrm{~B}+i \mathrm{PrOLi}$ & 12 & $84(82)$ \\
\hline
\end{tabular}

[a] Molar percentages of $\mathrm{Ni}(\mathrm{cod})_{2}$, ligands, and additives are based on the amount of 2a. Reaction conditions: Ni(cod) 2 (0.025 mmol), 1 (2.3 mmol), $\mathbf{2 a}$ $(0.50 \mathrm{mmol})$, and toluene $(2.0 \mathrm{~mL})$. [b] N.D. = Not detected. [c] Yield was determined by ${ }^{19} \mathrm{~F}$ NMR measurement using $\mathrm{PhCF}_{3}$ as an internal standard. Isolated yield is shown in parentheses. [d] $\mathrm{KH}$ (5 mol\%) was added. [e] 2a (2.3 $\mathrm{mmol})$.

With the optimal conditions in hand, the scope of the reaction was investigated using various alkynes (Table 2 ). Diarylacetylenes $\mathbf{2} \mathbf{b}-\mathbf{e}$ bearing electron-donating groups ( $m$-Me, $p$-Me, $p$-Bu, and $p$-OMe) underwent cycloaddition effectively to afford the corresponding tetraarylated fluorobenzenes $\mathbf{3 b}-\mathbf{e}$ in $72 \%, 81 \%, 79 \%$, and $80 \%$ yields (Entries $2-5$ ), respectively. The reaction of diarylacetylene $2 f$ bearing electron-withdrawing $\mathrm{CF}_{3}$ groups also proceeded to give $\mathbf{3 f}$ in $76 \%$ yield (Entry 6). Chlorine-substituted diarylacetylene $\mathbf{2 g}$ underwent catalytic cycloaddition without loss of $\mathrm{Cl}$ groups (Entry 7). Aliphatic alkyne $2 \mathrm{~h}$ participated in the reaction to provide tetraalkylated fluorobenzene $\mathbf{3 h}$ in $79 \%$ yield (Entry 8). Ester, benzyl ether, acetal, and silyl ether moieties on dialkylacetylenes $\mathbf{2} \mathbf{i}-\mathbf{I}$ were tolerant in this reaction, which effectively afforded the corresponding fluoroarenes $\mathbf{3 i}-\mathbf{I}$ (Entries 9-12). The cycloaddition of unsymmetrical alkynes $2 \mathrm{~m}$ and $\mathbf{2 n}$ proceeded with substantial regioselectivities (84:16 and 85:15) to afford o- terphenyl derivatives $\mathbf{3 m}$ and $\mathbf{3 n}$ as major products (Entries 13 and 14$)$, respectively. ${ }^{[16,17]}$

Table 2. Ni-Catalyzed Synthesis of Fluoroarenes 3 from 1,1-Difluoroethylene (1) and Alkynes $2^{[a]}$

\begin{tabular}{|c|c|c|c|c|c|}
\hline & 1 & 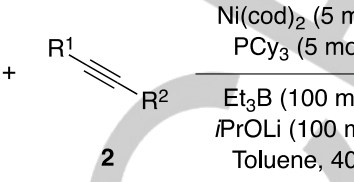 & $\begin{array}{l}\text { (\%) } \\
\%) \\
\%) \\
\mathrm{O} \% \\
\mathrm{C}\end{array}$ & $\mathrm{R}^{2}$ & $2^{2}$ \\
\hline Entry & 2 & $\mathrm{R}^{1}, \mathrm{R}^{2}$ & Time [h] & 3 & Yield [\%] \\
\hline 1 & $2 a$ & $\mathrm{Ph}, \mathrm{Ph}$ & 12 & $3 a$ & 82 \\
\hline 2 & $2 b$ & $\mathrm{C}_{6} \mathrm{H}_{4}(m-\mathrm{Me}), \mathrm{C}_{6} \mathrm{H}_{4}(m-\mathrm{Me})$ & 16 & $3 b$ & 72 \\
\hline 3 & 2c & $\mathrm{C}_{6} \mathrm{H}_{4}(p-\mathrm{Me}), \mathrm{C}_{6} \mathrm{H}_{4}(p-\mathrm{Me})$ & 12 & $3 c$ & 81 \\
\hline 4 & $2 d$ & $\mathrm{C}_{6} \mathrm{H}_{4}(p-\mathrm{Bu}), \mathrm{C}_{6} \mathrm{H}_{4}(p-\mathrm{Bu})$ & 12 & 3d & 79 \\
\hline 5 & $2 e$ & $\mathrm{C}_{6} \mathrm{H}_{4}(p-\mathrm{OMe}), \mathrm{C}_{6} \mathrm{H}_{4}(p-\mathrm{OMe})$ & 12 & $3 e$ & 80 \\
\hline 6 & $2 f$ & $\mathrm{C}_{6} \mathrm{H}_{4}\left(p-\mathrm{CF}_{3}\right), \mathrm{C}_{6} \mathrm{H}_{4}\left(p-\mathrm{CF}_{3}\right)$ & 15 & $3 f$ & 76 \\
\hline 7 & $2 g$ & $\mathrm{C}_{6} \mathrm{H}_{4}(m-\mathrm{Cl}), \mathrm{C}_{6} \mathrm{H}_{4}(m-\mathrm{Cl})$ & 12 & $3 \mathbf{g}$ & 45 \\
\hline 8 & $2 \mathrm{~h}$ & $\mathrm{Pr}, \mathrm{Pr}$ & 15 & $3 \mathrm{~h}$ & 79 \\
\hline 9 & $2 i$ & $\left(\mathrm{CH}_{2}\right)_{2} \mathrm{CO}_{2} t \mathrm{Bu},\left(\mathrm{CH}_{2}\right)_{2} \mathrm{CO}_{2} t \mathrm{Bu}$ & 16 & $3 \mathbf{i}$ & 39 \\
\hline 10 & $2 \mathrm{j}$ & $\left(\mathrm{CH}_{2}\right)_{3} \mathrm{OCH}_{2} \mathrm{Ph},\left(\mathrm{CH}_{2}\right)_{3} \mathrm{OCH}_{2} \mathrm{Ph}$ & 14 & $3 \mathbf{j}$ & 58 \\
\hline 11 & $2 k$ & $\left(\mathrm{CH}_{2}\right)_{3} \mathrm{OTHP},\left(\mathrm{CH}_{2}\right)_{3} \mathrm{OTHP}$ & 14 & $3 k$ & 67 \\
\hline 12 & 21 & $\left(\mathrm{CH}_{2}\right)_{3} \mathrm{OSiMe}{ }_{3},\left(\mathrm{CH}_{2}\right)_{3} \mathrm{OSiMe}_{3}$ & 14 & 31 & 62 \\
\hline 13 & $2 m$ & $\mathrm{Me}, \mathrm{Ph}$ & 18 & $3 m$ & $59^{[b]}$ \\
\hline 14 & $2 n$ & $\mathrm{Pr}, \mathrm{C}_{6} \mathrm{H}_{4}(p-\mathrm{OMe})$ & 14 & $3 n$ & $60^{[c]}$ \\
\hline
\end{tabular}

[a] Molar percentages of $\mathrm{Ni}(\mathrm{cod})_{2}, \mathrm{PCy}_{3}, \mathrm{Et}_{3} \mathrm{~B}$, and $\mathrm{PrOLi}$ are based on the amount of 2. Reaction conditions: $\mathrm{Ni}(\operatorname{cod})_{2}(0.12 \mathrm{mmol}), \mathrm{PC}_{3}(0.12 \mathrm{mmol}), 1$ $(2.3 \mathrm{mmol}), 2(2.3 \mathrm{mmol}), \mathrm{Et}_{3} \mathrm{~B}(2.3 \mathrm{mmol})$, iPrOLi $(2.3 \mathrm{mmol})$, and toluene $(4.7$ $\mathrm{mL}$ ). [b] Isolated yield. [c] The regioisomer ratio (84:16) was determined by ${ }^{19} \mathrm{~F}$ NMR measurement. [d] The regioisomer ratio $(85: 15)$ was determined by ${ }^{19} \mathrm{~F}$ NMR measurement.

To gain some insights into the reaction mechanism, the initial rate of the formation of product $\mathbf{3 a}\left((\Delta[\mathbf{3} \mathbf{a}] / \Delta t)_{t=0}\right)$ was measured. We first monitored the dependency of $(\Delta[3 \mathbf{a}] / \Delta t)_{t=0}$ by changing the partial pressure of $\mathbf{1}(p(\mathbf{1}) ; 0.3-1.0 \mathrm{~atm})$. A linear correlation between $p(\mathbf{1})$ and $(\Delta[\mathbf{3} \mathbf{a}] / \Delta t)_{t=0}$ (Figure 1a) was obtained. Furthermore, a straight line (slope $=1.12$ ) provided a good fit for the log-log plot of $(\Delta[\mathbf{3} \mathbf{a}] / \Delta t)_{t=0}$ against $p(\mathbf{1})$, indicating that the reaction has a nearly first-order dependence on the concentration of $\mathbf{1}$ in the solution (Figure 1b). Next, the dependency of the initial rate $\left((\Delta[\mathbf{3} \mathbf{a}] / \Delta t)_{t=0}\right)$ on the initial concentration of alkyne $\mathbf{2 a}\left([\mathbf{2} \mathbf{a}]_{0} ; 0.2-0.9 \mathrm{M}\right)$ under a constant pressure $(1.0 \mathrm{~atm})$ of 1 was examined. A linear correlation between the two was observed (Figure 1c). The linear fitting of the log-log plot with a slope of 1.02 shows a first-order dependence of the reaction rate on $[\mathbf{2} \mathbf{a}]_{0}$ (Figure $1 \mathrm{~d}$ ). Furthermore, the dependency of $(\Delta[\mathbf{3 a}] / \Delta t)_{t=0}$ on the initial 
concentration of the $\mathrm{Ni}(0)$ complex $\left([\mathrm{Ni}]_{0} ; 0.013-0.11 \mathrm{M}\right)$ was estimated by reactions with a constant concentration $(0.25 \mathrm{M})$ of 2a under a constant pressure (1.0 atm) of $\mathbf{1}$ in the absence of $\mathrm{Et}_{3} \mathrm{~B}$ and $i \mathrm{PrOLi}$. Not only a linear correlation between $[\mathrm{Ni}]_{0}$ and $(\Delta[\mathbf{3} \mathbf{a}] / \Delta t)_{t=0}$ (Figure 1e) but also the linear fitting of the log-log plot (slope: 1.09) clearly exhibits a first-order dependence of the reaction rate on $[\mathrm{Ni}]_{0}$ (Figure $1 \mathrm{f}$ ). These results suggest that the initial rate-limiting oxidative cyclization proceeds with the involvement of one component each of $\mathbf{1}, \mathbf{2} \mathbf{a}$, and $\mathrm{Ni}(0){ }^{[18]}$
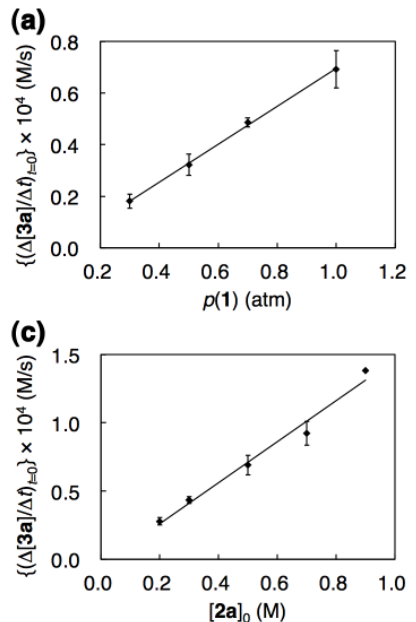

(e)
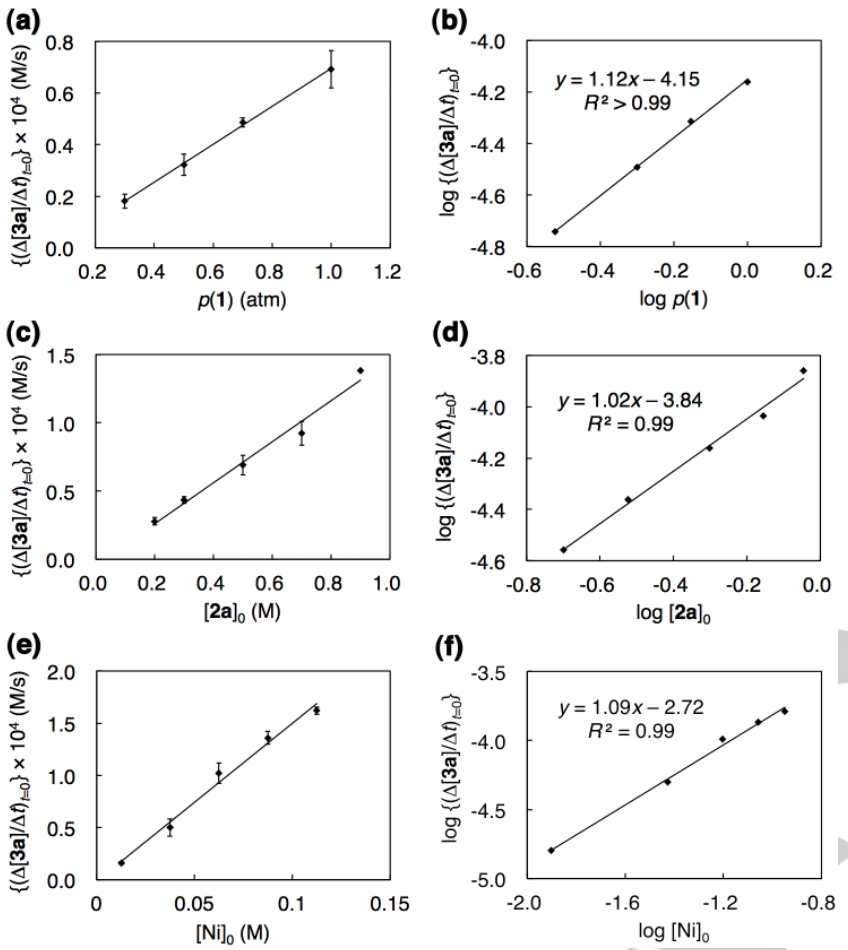

(d)

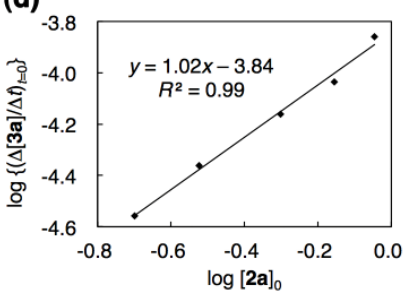

(f)

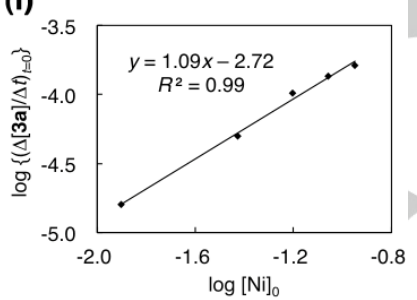

Figure 1. (a) Initial reaction rate versus $p(\mathbf{1})$ and (b) the corresponding log-log plot. Reaction conditions: $\mathrm{Ni}(\mathrm{cod})_{2}(0.025 \mathrm{mmol}), \mathrm{PC}_{3}(0.025 \mathrm{mmol}), 1$ (partial pressure: $0.30-1.0 \mathrm{~atm}), 2 \mathrm{2a}(0.50 \mathrm{mmol}), \mathrm{Et}_{3} \mathrm{~B}(0.50 \mathrm{mmol}), i \operatorname{PrOLi}(0.50$ $\mathrm{mmol})$, and toluene $(1.0 \mathrm{~mL})$ at $40{ }^{\circ} \mathrm{C}$ for $15 \mathrm{~min}$. (c) Initial reaction rate versus $[2 \mathbf{a}]_{0}$ and (d) the corresponding log-log plot. Reaction conditions: Ni(cod) (0.025 mmol), $\mathrm{PC}_{3}(0.025 \mathrm{mmol}), 1$ (excess in balloon, $\left.1 \mathrm{~atm}\right), 2 \mathrm{2a}(0.20-0.90$ $\mathrm{mmol}), \mathrm{Et}_{3} \mathrm{~B}(0.50 \mathrm{mmol})$, PrOLi $(0.50 \mathrm{mmol})$, and toluene $(1.0 \mathrm{~mL})$ at $40{ }^{\circ} \mathrm{C}$ for $15 \mathrm{~min}$. (e) Initial reaction rate versus [ $\mathrm{Ni}]_{0}$ and $(f)$ the corresponding log-log plot. Reaction conditions: $\mathrm{Ni}(\mathrm{cod})_{2}(0.013-0.11 \mathrm{mmol}), \mathrm{PCy}_{3}(0.013-0.11$ $\mathrm{mmol}), 1$ (excess in balloon, $1 \mathrm{~atm}), 2 \mathrm{a}(0.25 \mathrm{mmol})$, and toluene $(1.0 \mathrm{~mL})$ at $40^{\circ} \mathrm{C}$ for $5 \mathrm{~min}$.

To elucidate the mechanism further, the stoichiometric reaction of 1,1-difluoro-1,6-enyne $\mathbf{5}$ and alkyne $\mathbf{2} \mathbf{a}$ with $\mathrm{Ni}(0)$ was performed. Treatment of equimolar amounts of enyne $\mathbf{5}$ and alkyne $2 \mathrm{a}$ with stoichiometric amounts of $\mathrm{Ni}(\mathrm{cod})_{2}$ and $\mathrm{PCy}_{3}$ afford the ring-monofluorinated indane 6 in $60 \%$ yield [Eq. (1)]. Since one difluoroalkene moiety and two alkyne components were involved in the formation of $\mathbf{6}$, we presumed that this reaction proceeded through a cycloaddition process similar to that in the case of the reaction involving $\mathbf{1}$ and $\mathbf{2}$. The formation of $\mathbf{6}$ is likely to involve the initial intramolecular oxidative cyclization of difluoroalkene and alkyne moieties in $\mathbf{5}$ with $\mathrm{Ni}(0) \cdot{ }^{[19,20]}$ This cyclization mode would be consistent with the aforementioned result of the reaction between $\mathbf{1}$ and $\mathbf{2 a}$. Correspondingly, the oxidative cyclization of $\mathbf{1}, \mathbf{2}$, and $\mathrm{Ni}(0)$ probably affords the intermediate nickelacyclopentenes, wherein the difluoromethylene moiety regioselectively occupies the position $\alpha$ to the nickel atom.

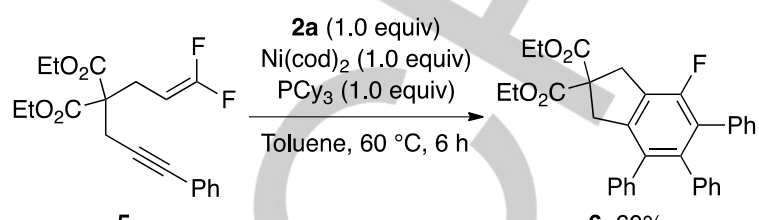

Taken together, these observations suggest a plausible mechanism for the $\mathrm{Ni}(0)$-catalyzed cycloaddition (Scheme 2). This reaction starts with oxidative cyclization, rate-limiting chemo- and regioselective formation of nickelacyclopentenes $\mathbf{A}$, resulting from the combination of one molecule each of $\mathbf{1}$ and $\mathbf{2}$. The nickelacyclopentenes $\mathbf{A}$ thus formed facilitates the insertion of another molecule of $\mathbf{2}$ to generate nickelaheptadienes $\mathbf{B}$. Subsequent $\alpha$-fluorine elimination from $\mathbf{B}$ gives cyclohexadienylnickel(II) fluorides $\mathbf{C}^{[14,15]}$ Finally, $\beta$-hydrogen elimination affords fluoroarenes $\mathbf{3}$ and nickel(II) hydrofluoride $\mathbf{D}$, which can then be reduced to $\mathrm{Ni}(0)$ complex via transmetalation with the borate derived from $\mathrm{Et}_{3} \mathrm{~B}$ and iPrOLi. ${ }^{[21]}$

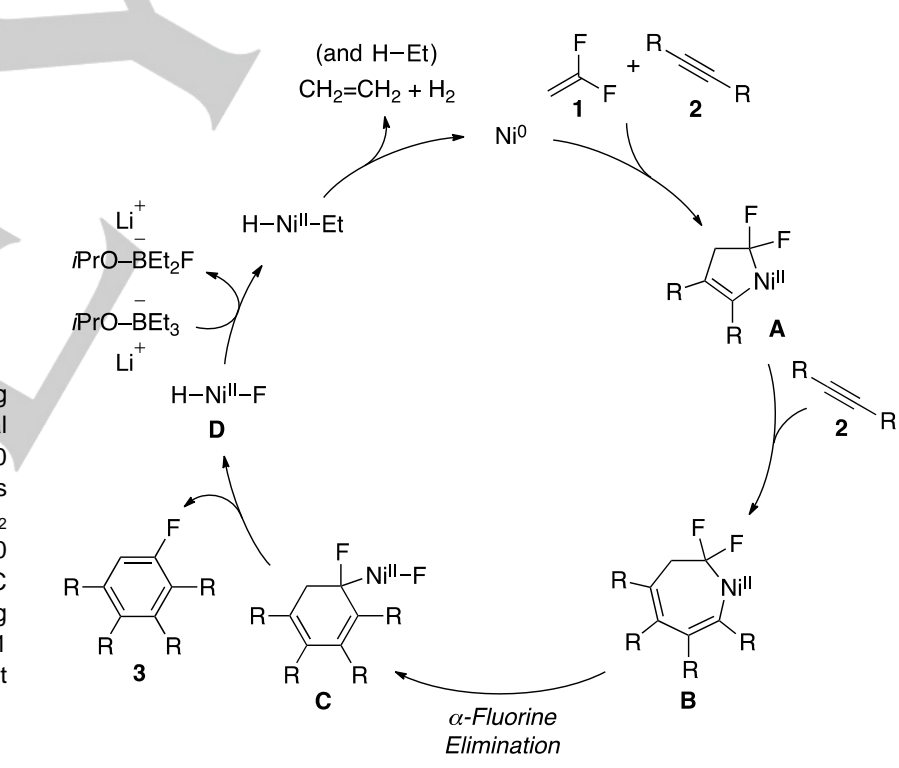

Scheme 2. Plausible reaction mechanism.

The obtained tetraarylated fluoroarene products can serve as building blocks in further transformations. For example, treatment of fluoroarene $\mathbf{3 d}$ with excess $\mathrm{FeCl}_{3}$ led to ring fusions via three oxidative $\mathrm{C}-\mathrm{H} / \mathrm{C}-\mathrm{H}$ couplings ${ }^{[22]}$ to afford tribenzoperylene 7 with the fluorine substituent in $74 \%$ yield [Eq. (2)].[23] The resulting pinpoint-fluorinated planar $\pi$-conjugated system can be a promising candidate as organic electronic material. ${ }^{[24]}$ 
In summary, we developed a nickel-catalyzed method for direct synthesis of fluoroarenes via $\alpha$-fluorine elimination. This method for fluoroarene synthesis complements conventional methods, which install fluorine on preformed benzene rings. With proper choice of alkyne substrates, our method enables modular synthesis of diversely substituted fluoroarenes ${ }^{[25]}$ from 1,1-difluoroethylene, an industrial material.

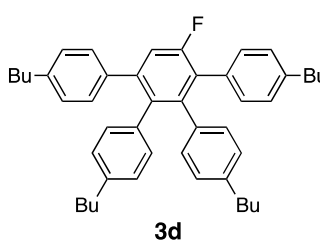

$3 d$

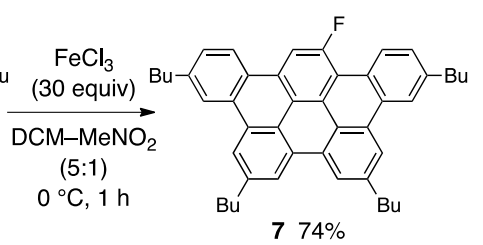

\section{Experimental Section}

Typical procedure for the synthesis of fluoroarenes $\mathbf{3}$ via nickel-catalyzed [2+2+2] cycloaddition: In an argon-purged 50-mL test tube equipped with a PTFE cap (EYELA, PPS25-TC) were placed $\mathrm{PrOH}$ (179 and toluene $(2.4 \mathrm{~mL})$. To the mixture was slowly added $n \mathrm{BuLi}(1.58 \mathrm{M}$ in hexane, $1.47 \mathrm{~mL}, 2.32 \mathrm{mmol}$ ) at $0{ }^{\circ} \mathrm{C}$. After stirring for $10 \mathrm{~min}$ at $0{ }^{\circ} \mathrm{C}$, $\mathrm{BEt}_{3}(1.0 \mathrm{M}$ in hexane, $2.32 \mathrm{~mL}, 2.3 \mathrm{mmol})$ was added to the reaction mixture at the same temperature. The reaction mixture was warmed to room temperature, and was stirred for another $30 \mathrm{~min}$. To the reaction mixture were added diphenylacetylene (2a, $414 \mathrm{mg}, 2.32 \mathrm{mmol}), \mathrm{Ni}(\mathrm{cod})_{2}$ (32 mg, $0.12 \mathrm{mmol}), \mathrm{PCу}_{3}(33 \mathrm{mg}, 0.12 \mathrm{mmol})$, and toluene $(2.3 \mathrm{~mL})$. The reaction vessel was evacuated, filled with 1,1-difluoroethylene (1, $1.0 \mathrm{~atm}$ $56 \mathrm{~mL}, 2.3 \mathrm{mmol}$ ) through a balloon, and then sealed by closing the stopcock of the PTFE cap. After stirring for $12 \mathrm{~h}$ at $40{ }^{\circ} \mathrm{C}$, the reaction mixture was filtered through a pad of silica gel (EtOAc). The filtrate was concentrated under reduced pressure. The residue was purified by silica gel column chromatography (hexane/EtOAc $=20: 1$ ) to give fluoroarene $\mathbf{3 a}$ as a white solid (380 $\mathrm{mg}, 82 \%)$.

\section{Acknowledgements}

This work was supported by the Grant-in-Aid for Scientific Research (B) (No. 25288016) and the Grant-in-Aid for Young Scientists (B) (No. 26870079) from JSPS. This work was also supported by The Asahi Glass Foundation. We acknowledge Tosoh F-Tech, Inc. for generous gifts of 1,1-difluoroethylene and 3-bromo-3,3-difluoropropene.

Keywords: C-F bond activation $\bullet$ fluoroarenes $\bullet \mathrm{Ni} \bullet$ fluoroalkenes • alkynes

[1] For reviews, see: a) V. V. Grushin, Acc. Chem. Res. 2010, 43, 160171; b) T. Furuya, J. E. M. N. Klein, T. Ritter, Synthesis 2010, 1804 1821; c) T. Furuya, A. S. Kamlet, T. Ritter, Nature 2011, 473, 470-477; d) C. Hollingworth, V. Gouverneur, Chem. Commun. 2012, 48, 2929 2942; e) Y. Li, Y. Wu, G.-S. Li, X.-S. Wang, Adv. Synth. Catal. 2014 356, 1412-1418; f) A. F. Brooks, J. J. Topczewski, N. Ichiishi, M. S. Sanford, P. J. H. Scott, Chem. Sci. 2014, 5, 4545-4553; g) M. G. Campbell, T. Ritter, Chem. Rev. 2015, 115, 612-633.

[2] a) A. Roe, Org. React. 1949, 5, 193-228; b) K. K. Laali, V. J. Gettwert, J. Fluorine Chem. 2001, 107, 31-34, and references cited therein.
[3] a) D. J. Adams, J. H. Clark, Chem. Soc. Rev. 1999, 28, 225-231; b) M.A. Lacour, M. Zablocka, C. Duhayon, J.-P. Majoral, M. Taillefer, Adv. Synth. Catal. 2008, 350, 2677-2682, and references cited therein.

[4] For recent reports, see: a) C. Cazorla, E. Métay, B. Andrioletti, M. Lemaire, Tetrahedron Lett. 2009, 50, 3936-3938; b) S. Yamada, A. Gavryushin, P. Knochel, Angew. Chem. 2010, 122, 2261-2264; Angew. Chem. Int. Ed. 2010, 49, 2215-2218; c) P. Anbarasan, H. Neumann, M. Beller, Angew. Chem. 2010, 122, 2265-2268; Angew. Chem. Int. Ed. 2010, 49, 2219-2222.

[5] For recent reports, see: a) V. V. Grushin, W. J. Marshall, Organometallics 2008, 27, 4825-4828; b) B. Wang, L. Qin, K. D. Neumann, S. Uppaluri, R. L. Cerny, S. G. DiMango, Org. Lett. 2010, 12 3352-3355; c) M. Saito, K. Miyamoto, M. Ochiai, Chem. Commun 2011, 47, 3410-3412; d) P. Tang, W. Wang, T. Ritter, J. Am. Chem. Soc. 2011, 133, 11482-11484; e) H. Yoshida, R. Yoshida, K. Takaki, Angew. Chem. 2013, 125, 8791-8794; Angew. Chem. Int. Ed. 2013, 52, 8629-8632.

[6] a) K. L. Hull, W. Q. Anani, M. S. Sanford, J. Am. Chem. Soc. 2006, 128, 7134-7135; b) T. Truong, K. Klimovica, O. Daugulis, J. Am. Chem. Soc. 2013, 135, 9342-9345.

[7] P. Tang, T. Furuya, T. Ritter, J. Am. Chem. Soc. 2010, 132, 1215012154.

[8] D. A. Watson, M. Su, G. Teverovskiy, Y. Zhang, J. García-Fortanet, T. Kinzel, S. L. Buchwald, Science 2009, 325, 1661-1664.

2.3 mmol $\min _{\text {T. Ichitsuka, T. Fujita, T. Arita, J. Ichikawa, Angew. Chem. 2014, } 126}$ 7694-7698; Angew. Chem. Int. Ed. 2014, 53, 7564-7568.

[10] For transition-metal-mediated reactions via $\beta$-fluorine elimination, see a) W. Heitz, A. Knebelkamp, Makromol. Chem. Rapid Commun. 1991 12, 69-75; b) M. Fujiwara, J. Ichikawa, T. Okauchi, T. Minami Tetrahedron Lett. 1999, 40, 7261-7265; c) K. Sakoda, J. Mihara, J. Ichikawa, Chem. Commun. 2005, 4684-4686; d) J. Ichikawa, K Sakoda, J. Mihara, N. Ito, J. Fluorine Chem. 2006, 127, 489-504; e) J. Ichikawa, R. Nadano, N. Ito, Chem. Commun. 2006, 4425-4427; f) T. Miura, Y. Ito, M. Murakami, Chem. Lett. 2008, 37, 1006-1007; g) M. Hu, Z. He, B. Gao, L. Li, C. Ni, J. Hu, J. Am. Chem. Soc. 2013, 135, 17302 17305; h) D. J. Harrison, G. M. Lee, M. C. Leclerc, I. Korobkov, R. T. Baker, J. Am. Chem. Soc. 2013, 135, 18296-18299; i) Z. Zhang, Q. Zhou, W. Yu, T. Li, G. Wu, T. Zhang, J. Wang, Org. Lett. 2015, 17, 2474-2477.

[11] For reviews on transition-metal-catalyzed [2+2+2] cycloaddition, see: a) M. Lautens, W. Klute, W. Tam, Chem. Rev. 1996, 96, 49-92; b) P. A Inglesby, P. A. Evans, Chem. Soc. Rev. 2010, 39, 2791-2805; c) G. Domínguez, J. Pérez-Castells, Chem. Soc. Rev. 2011, 40, 3430-3444.

[12] For Ni-catalyzed [2+2+2] reactions between one molecule of alkenes and two molecules of alkynes, see: a) S.-i. Ikeda, N. Mori, Y. Sato, J. Am. Chem. Soc. 1997, 119, 4779-4780; b) S.-i. Ikeda, H. Watanabe, Y. Sato, J. Org. Chem. 1998, 63, 7026-7029; c) T. Sambaiah, L.-P. Li, D.J. Huang, C.-H. Lin, D. K. Rayabarapu, C.-H. Cheng, J. Org. Chem 1999, 64, 3663-3670; d) Z. Qiu, Z. Xie, Angew. Chem. 2009, 121 5839-5842; Angew. Chem. Int. Ed. 2009, 48, 5729-5732; e) H. Horie T. Kurahashi, S. Matsubara, Chem. Commun. 2010, 46, 7229-7231.

[13] a) H. Hara, M. Hirano, K. Tanaka, Org. Lett. 2008, 10, 2537-2540; b) H. Tsuji, K.-i. Yamagata, T. Fujimoto, E. Nakamura, J. Am. Chem. Soc. 2008, 130, 7792-7793; c) Y. Kuninobu, M. Nishi, S. S. Yudha, K. Takai Org. Lett. 2008, 10, 3009-3011; d) H. Hara, M. Hirano, K. Tanaka, Org. Lett. 2009, 11, 1337-1340; e) K. Zhang, J. Louie, J. Org. Chem. 2011 76, 4686-4691.

[14] For a review on transition-metal-mediated $\alpha$-fluorine elimination, see: $R$ P. Hughes, Eur. J. Inorg. Chem. 2009, 4591-4606.

[15] M. Takachi, Y. Kita, M. Tobisu, Y. Fukumoto, N. Chatani, Angew. Chem 2010, 122, 8899-8902; Angew. Chem. Int. Ed. 2010, 49, 8717-8720.

[16] Structures of major and minor regioisomers were characterized by $2 \mathrm{D}$ NMR measurements. Minor products were thus found to be $m$ terphenyl derivatives. For details, see Supporting Information. For regioselectivity on nickel-catalyzed coupling reactions of alkynes via 
oxidative cyclization, see: P. Liu, P. McCarren, P. H.-Y. Cheong, T. F. Jamison, K. N. Houk, J. Am. Chem. Soc. 2010, 132, 2050-2057.

[17] Reactions with terminal alkynes such as 1-hexyne, phenylacetylene, and trimethylsilylacetylene afforded the corresponding fluoroarenes albeit in $5 \%, 3 \%$, and $5 \%$ yields (determined by ${ }^{19} \mathrm{~F}$ NMR measurement using $\mathrm{PhCF}_{3}$ as an internal standard), respectively.

[18] A stepwise oxidative cyclization model satisfactorily illustrates the experimental results. This stepwise model consists of (i) rapid preequilibrium between the reactants $(\mathrm{Ni}(0)$ and 1 ) and the intermediary nickelacyclopropane (see ref. 9) and (ii) subsequent slow insertion of 2 into the nickelacyclopropane. For details, see Supporting Information.

[19] The proposed oxidative cyclization is supported by Hoberg's and Chatani's reports. See: a) H. Hoberg, D. Guhl, J. Organomet. Chem. 1989, 378, 279-292; b) Ref. 15. See also, M. Takachi, N. Chatani, Org. Lett. 2010, 12, 5132-5134.

[20] In the case of the reaction of 1,1-difluoro-1,6-enyne $\mathbf{5}$ with diphenylacetylene (2a), $\beta$-hydrogen elimination yielding the corresponding fluoroarene $\mathbf{6}$ was sluggish, probably due to the rigid bicyclic system of the intermediate. Thus, in the presence of the reductant, $\mathrm{Et}_{3} \mathrm{~B}-\mathrm{P} \mathrm{PrOLi}$, transmetalation from the intermediary
cyclohexadienylnickel(II) fluoride corresponding to $\mathbf{C}$ in Scheme 2 preferably occured rather than $\beta$-hydrogen elimination, leading to the cyclohexadiene. To avoid confusion, we herein demonstrate that the stoichiometric reaction, conducted in the absence of the reductant, selectively afforded the corresponding fluoroarene 6 (eq 1).

[21] Since generation of ethylene and dihydrogen during the reaction was confirmed by each gas detector, a $\beta$-hydrogen elimination-reductive elimination sequence definitely occurred as a route from $\mathrm{Ni}(\mathrm{II})$ to $\mathrm{Ni}(0)$.

[22] For a review on oxidative $\mathrm{C}-\mathrm{H} / \mathrm{C}-\mathrm{H}$ coupling, see: a) A. A. O. Sarhan C. Bolm, Chem. Soc. Rev. 2009, 38, 2730-2744; b) M. Grzybowski, K Skonieczny, H. Butenschön, D. T. Gryko, Angew. Chem. 2013, 125, 10084-10115; Angew. Chem. Int. Ed. 2013, 52, 9900-9930.

[23] M. Danz, R. Tonner, G. Hilt, Chem. Commun. 2012, 48, 377-379.

[24] K. Fuchibe, T. Morikawa, K. Shigeno, T. Fujita, J. Ichikawa, Org. Lett. 2015, 17, 1126-1129.

[25] For a modular synthesis of substituted fluoroarenes, see: Y. Wang, D. J. Burton, Tetrahedron Lett. 2006, 47, 9279-9281. 
Entry for the Table of Contents (Please choose one layout)

Layout 1:

\section{COMMUNICATION}

A method for direct synthesis of tetrasubstituted fluoroarenes via nickel-catalyzed [2+2+2] cycloaddition is presented. The reaction combines one molecule of 1,1-difluoroethylene with two molecules of alkynes and involves sequential cleavage of the $\mathrm{C}$ $\mathrm{F}$ and $\mathrm{C}-\mathrm{H}$ bonds in difluoroethylene. The catalytic cycle is established by reduction of the intermediary $\mathrm{Ni}(\mathrm{II})$ fluoride with a triethylborane-based borate.

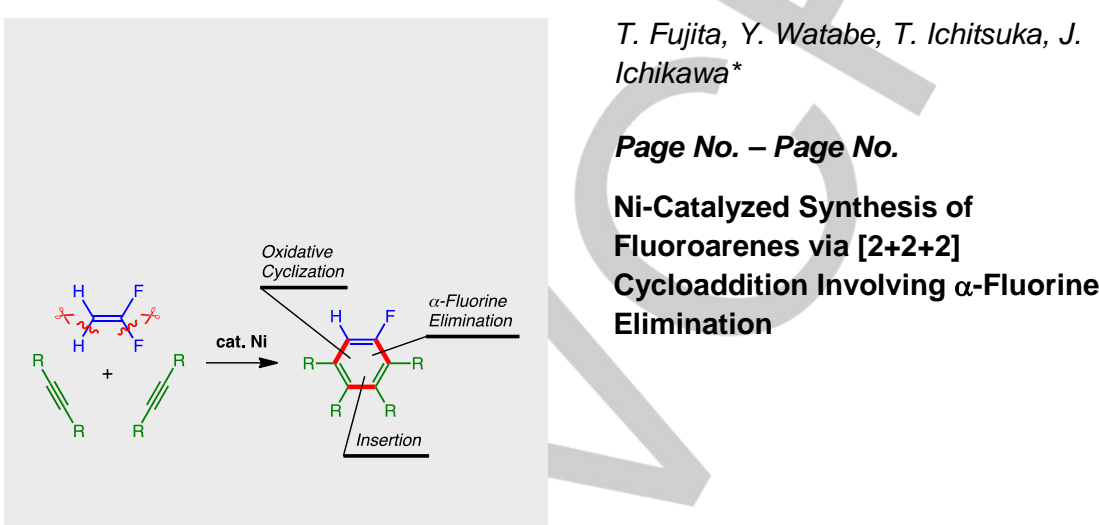

